\title{
EFFECTS OF PROPRIOCEPTIVE TRAINING ON EXPLOSIVE STRENGHT, AGLILITY AND COORDINATION OF YOUNG RHYTHMIC GYMNASTS
}

\author{
Slobodanka M. Dobrijević, Lidija Moskovljević, Miloš Marković, Milinko Dabović \\ University of Belgrade, Faculty of Sport and Physical Education, Belgrade, Serbia
}

\begin{abstract}
The aim of this study was to examine the influence of proprioceptive training on explosive strength, agility and coordination in young rhythmic gymnasts. The study was conducted on a sample of 74 healthy girls, aged 7 to 9 years of age who train rhythmic gymnastics. The whole sample was divided into two groups: experimental (43 girls) and control (31 girls). The experimental group had the proprioception training before their regular trainings for 12 weeks (24 trainings), while the control group had only rhythmic gymnastics trainings. Effects of proprioceptive trainings on the examined motor abilities were estimated by two explosive strength tests, three coordination tests and two agility tests. All respondents were tested before the application of the experimental treatment (pre-test) and after its completion (post-test). To examine differences in the achieved results between the initial and final measurement for each group, t-test for dependent samples was used. To determine differences between groups at the initial and final measurement, t-test for independent samples was used. By comparing results from the initial and final measurement, improvement in all tests for the observed abilities was perceived in the experimental group, while improvement in coordination tests and one agility test was noticed in the control group. Testing differences in results between groups in the final measurement showed that there are differed only in agility tests, and in favour of the experimental group. Based on the obtained results, the conclusion was that the application of proprioceptive training in rhythmic gymnasts can contribute to improvement of agility, while in other observed abilities we cannot conclusively claim that improvement was the direct product of proprioceptive training.
\end{abstract}

Key words: PROPRIOCEPTIVENESS/ RHYTHMIC GYMNASTIC/ GIRLS

\section{INTRODUCTION}

Motor abilities are in the basis of every physical activity, from usual, everyday movements to performance of various sport techniques. They significantly contribute to biological but also to psychological and social aspects of life, and care of their development multiplies the invested effort through health improvement and building of emotionally stable personality with an adequate social status.

Given the importance of motor abilities, they are often subject for research. Professionals constantly search for different training methods and types of training that can contribute to their improvement, especially in the period of growth and development.
Proprioceptive training is the type of training whose influence on different motor abilities has not been fully investigated. It is directed towards the stimulation of proprioceptors with the aim to provoke adequate motor response, which primarily contributes to stability of joints and balance of the whole body, and then also more precise and more efficient performance of all kinds of movements. This improves proprioception itself as well as a series of other motor abilities, which, thanks to the timely reception of stimuli from proprioceptors, can be expressed more efficiently. The most important for the efficiency of expressing motor abilities are stimuli emerging from intrafusal muscle fibres, the so called "muscle spindles", Golgi tendon organs and Pacinian corpuscles. 
These receptors react to the changes in tension and length of muscles and tendons, at speed of these changes, as well as changes in posture of the body and parts of the body (Harris \& Dudley 2000; Lephart \& Fu 2000). Excitation of these receptors are transferred along afferent pathways to lower or higher level of the central nervous system, so that the timely activation of the adequate motor units enables sustaining stability of the body during static and dynamic activities (Laskowski, Newcomer-Aney, \& Smith, 1997).

Proprioceptive training was first used in rehabilitation, most often in ankle and knee injuries. It was found that its application improved the functional stability of joints, that it contributed to improvement of the clinical picture in disturbed postural status and significantly reduces the frequency of repeated injuries (Irrgang et al., 1994; Weste et al., 1996; Bernier \& Perrin, 1998; Elis \& Rosenbaum, 2001; Vad et al., 2002; Liu Ambrose et al., 2003). It was very quickly accepted in elite sports primarily as a prevention of injuries. A large number of authors emphasizes that the improvement of neuro-muscle response to excitation of kinaesthetic receptors can be a key factor in the effective reduction of the risk from injuries (Gauffin, Tropp \& Odenrick, 1988; Sheth et al., 1997; Robbins \& Waked, 1998; Eils, Schröter et al., 2010). Conscious movements initiated in the cerebral cortex are too slow to prevent an injury in urgent situations, and it is estimated that the spinal reflexes are those that contribute to quicker and timely activation of the stabiliser muscles (Laskowski et al., 1997).

In healthy persons positive effects of this training are primarily reflected in the improvement of the ability to keep the balance i.e., in reduction of postural oscillations (Hoffman \& Payne, 1995), while its influence on different motor abilities is not completely researched. Most authors examined the influence of proprioceptive training on the ability to balance and they all emphasize its positive influence on this ability, both in adults (Gioftsidou et al., 2006; Yaggie \& Campbell, 2006; Granacher, Gollhofer \& Kriemler, 2010; Romero-Franco et al., 2012), and in children (Dobrijević, Moskovljević and Dabović, 2016). When it comes to strength, various authors agree that the application of proprioceptive training has no influence on this motor ability, but that it positively affect the rate of force development (Gruber \& Gollhofer, 2004; Granacher et al., 2010).

Findings of different authors considering influence of proprioceptive training on the explosive strength and agility are different, often even opposed (Yaggie \& Campbell, 2006; Cressey et al., 2007; Šimek, Milanović \& Jukić. 2008; Granacher et al., 2010). There are insufficient data on influence of proprioceptive training on coordination (Lukić, 2010), and the existing ones do not offer clear answer to this question.

There are few data on the influence of proprioceptive training on the development of motor abilities in athletes, i.e. its place in the fitness preparation of athletes. Dobrijević et al. (2016) point out that the application of proprioceptive training in young rhythmic gymnasts can significantly contribute to the development of balance as one of crucial motor abilities for success in this sports branch. Some authors who investigated the influence of proprioceptive training on the specific sports technique (Wolf-Cvitak et al., 2002; Šebić-Zuhrić, Rađo and Bonacin, 2007), noted that, relying on the kinaesthetic feeling, learning certain movements in sports, such as rhythmic gymnastics, can significantly be sped up and that proprioceptive training represents a significant means for improvement of specific technique in rhythmic gymnastics.

Given that the influence of proprioceptive training on the explosive strength, agility and coordination is not completely examined, that the previous studies dealt with the sample of adults, and that there are data on the influence of this training on the specific technique, but not on the motor abilities in rhythmic gymnastics, there came the idea on realisation of this study. The aim of this study was to examine the influence of proprioceptive training on agility, coordination and explosive strength of leg muscles in young rhythmic gymnasts.

\section{METHOD}

This research represents a longitudinal study conducted on a sample of girls who train rhythmic gymnastics to examine the effects of proprioceptive training on agility, coordination and explosive strength of legs. 


\section{Samples}

The sample of respondents was comprised of 74 healthy girls (aged $8 \pm 0.8$ ) who have been training rhythmic amateur gymnastics in the "In" Gymnastic Club in Belgrade. All girls have been involved in this type of training for 1-2 years, and their training sessions are 60 minutes twice a week. Using the random sample method, they were divided into two groups, experimental (E) - 43 girls and control (K) 31 girls. Girls and their parents were informed about all details of the study, and the parents provided the written consent for participation of girls in the study.

\section{Experimental protocol}

All respondents were tested before the commencement of the experiment (initial measurement-T1) and after 12 weeks of the application of the experimental treatment (final measurement - T2). The sample of variables encompassed two variables for agility assessment, three for coordination and two for explosive leg strength assessment. All variables were measured with standardized tests whose validity and reliability had already been confirmed:

- Agility - 20 yards test (20Y) (Milanović, 2003) and Lateral agility test - change of direction lateral test (LAT) (Metikoš et al., 1989),

- Coordination - Twisting/agility in the air (OuV) (Kurelić et al. 1975), Figure eight with bending and jumping (OsS) (Eurofit, 1988), Jumping over and pulling under (PiP) - (Metikoš et al., 1989),

- Explosive strength of leg muscles - Countermovement jump (CMJ) (Enoksen, Tonnessen \& Shalfawi, 2009) and Standing long jump test (LJ) (Eurofit, 1988).

\section{Testing}

The respondents were familiar with the test protocol before the beginning of measurement. Each respondent had one trial, followed by two measurements, and a better result was used for the analysis. Breaks between trials were 3-5 minutes, which was enough for the respondent recovery and to avoid a potential influence of fatigue in the subsequent performance (Spencer et al., 2008). Before each test, the respondents were instructed to finish the given task as quickly as possible in agility and coordination tests, while in explosive strength tests they were giv- en instructions to jump as high as possible (CMJ), or as long as possible (LJ). All tests were completed in the morning hours in the sport centre hall "Novi Beograd". During testing the respondents wore sports outfit.

20 yards test (20Y) is done by 20 -yard-run at maximum speed with one $90^{\circ}$ turn and two $180^{\circ}$ turns. In the initial position, the respondent is turned laterally in the direction of movement. The respondent starts from the middle; she runs to the right marker cone $(5 \mathrm{y}=4.55 \mathrm{~m})$, then to the left marker cone $(10 \mathrm{y}=9.1 \mathrm{~m})$, and at the end to the one in the middle $(5 \mathrm{y}=4.55 \mathrm{~m})$. Lateral agility test (LAT) is done by moving sideways (sideway steps) with maximum speed along the 4-meter drawn path. The respondent stands behind the start line, turned laterally in the direction of movement. She starts at the sign made by the person who measures time and moves along the path for 6 times $(6 \times 4 \mathrm{~m})$, without changing the orientation in space (only the direction of movement is changed).

Jumping over and pulling under (PiP) is done in the space $7.5 \mathrm{~m}$ long, where at each $1.5 \mathrm{~m}$ there is one segment of vertical vaulting box placed, the total of four, and $1.5 \mathrm{~m}$ behind the last segment there is the line for turning back. The respondent stands behind the start line and at the sign made by the person who measures time, she starts moving. She jumps over the first and crawls under the second to get through in both directions.

Twisting/agility in the air $(\mathrm{OuV})$ is done when the respondent starts moving from the position sitting on 4 medicine balls, facing the opposite direction to the direction of movement. At the sign of the person who is measuring, the respondent has to do backward roll as quickly as possible, stands up, and performs a forward roll over the medicine balls without touching them. After the forward roll, the respondent turns round for $180^{\circ}$ and touches all 4 medicine balls with her palms.

Figure eight with bending and jumping (OsS) is performed by moving between three posts placed in a line at the distance of $2.5 \mathrm{~m}$. The elastic tape is stretched between them, at hip height of the respondent between the first and the second, and at the knee height between the second and the third. The respondent should go round the post for as short time as possible bending down under the 
elastic tape placed at hip height and jumping over the elastic tape placed at knee height.

Long jump (LJ) is done on a flat, non-slippery surface marked with a place for jumping and for take-off. The task for the respondent is to jump as long as possible, and the distance is measured from the jump line from the place where the respondent touches the ground with her heels. Countermovement jump, CMJ is done on a contact surface (Newtest Powertimer, 300-series). The respondent stands upright on the surface with her feet as wide apart as hips. Then she performs countermovement jump with arm swing.

\section{Experimental program of proprioceptive training model}

In the period of 12 weeks (24 trainings), the experimental group had proprioceptive training before their regular rhythmic gymnastics trainings, while the control group had only regular trainings for that time. The proprioceptive training started $15 \mathrm{~min}$ utes before regular rhythmic gymnastics trainings, and partially continued during the regular training. This type of organization was applied because of the scope of work in the experimental and the control group, which was achieved because the time of active exercises and rest alternated in equal time intervals in proprioceptive training. The program of proprioceptive training was realized using various boards for this kind of training, such as T-board, wobble board, balance board, then with Pilates balls, low balance beam, soft mat. The participants were asked to maintain the balanced position for as long as possible on proprioceptive boards in unstable conditions, participants used the beam to perform exercise on the small surface of support, and the mat was used to stimulate the proprioceptrs by changing the quality of surface (performing exercise on hard and subsequently on soft surface). Different tasks were done with eyes open and closed, on one or both legs, and in later phases specific technique of rhythmic gymnastics was introduced (for example, balancing with a ball, rotating hoop or rope, throwing and catching...) all with the aim of making tasks more complex and increasing stimulation of proprioceptors. Proprioceptive training included warming up for 5 to 7 minutes and the main phase of the training organized by the method of stations. During each training session the respondents had 3 tasks done in 3 series with equal time of exercising and recovery between series (Jukić et al., 2003). The girls were most often organized in pairs, so that one was doing the exercise while the other had a rest. The contents of this program were realized at the beginning of the training, and the total duration of the active phase of proprioceptive training per respondent was not longer than 10 minutes, so that there would be no nervousness and muscular fatigue. A special attention was directed towards concentration of respondents at doing tasks, because it increased efficiency of flow of stimuli in central nervous system (Voight and Cook, 1996), which contributes to a greater efficiency of exercising.

\section{Statistical data processing}

Data collected in this study were arranged and processed in statistical procedures of Microsoft excel program, version 15 and SPSS 22.0. From the field of descriptive statistics, the arithmetic mean (Mean), standard deviation (SD) and standard error of the measurement (SEM) were calculated for each variable. Shapiro-Wilks test was used for testing normal distribution. From the field of comparative statistics, t-test for independent samples was used to determine differences in results between the control and experimental group separately for initial and final measurement, as well as the t-test for dependent samples to determine differences in results between the initial and final measurement.

\section{RESULTS}

Testing differences between groups at the initial measurement (Table 1) showed that they do not differ in any of the applied tests. 
Dobrijević M. S. et al., Effects of proprioceptive training.., PHYSICAL CULTURE 2018; 72 (1): 71-79

Table 1. Testing differences between groups at the initial and final measurement ( $t$-test for independent samples)

\begin{tabular}{|c|c|c|c|c|c|c|c|c|}
\hline \multicolumn{5}{|c|}{ Initial measurement } & \multicolumn{4}{|c|}{ Final measurement } \\
\hline & $\mathrm{E}$ & $\mathrm{K}$ & & & $\mathrm{E}$ & $\mathrm{K}$ & & \\
\hline Tests & Mean \pm SD & Mean \pm SD & $\mathrm{t}$ & $p$ & Mean \pm SD & Mean \pm SD & $\mathrm{t}$ & $p$ \\
\hline $20 \mathrm{Y}(\mathrm{sec})$ & $7.94 \pm 0.64$ & $8.16 \pm 0.52$ & -1.496 & 0.14 & $7.62 \pm 0.66$ & $8.30 \pm 1.04$ & -2.922 & 0.01 \\
\hline LAT (sec) & $16.26 \pm 1.45$ & $16.88 \pm 1.60$ & -1.647 & 0.10 & $14.93 \pm 1.37$ & $15.77 \pm 1.86$ & -2.041 & 0.05 \\
\hline $\mathrm{PiP}(\mathrm{sec})$ & $19.36 \pm 4.45$ & $18.75 \pm 4.03$ & 0.562 & 0.58 & $18.07 \pm 4.08$ & $16.91 \pm 3.28$ & 1.153 & 0.25 \\
\hline $\mathrm{OuV}(\mathrm{sec})$ & $7.38 \pm 1.55$ & $7.69 \pm 1.61$ & -0.771 & 0.44 & $6.22 \pm 1.21$ & $6.72 \pm 1.22$ & -1.564 & 0.12 \\
\hline OsS (sec) & $8.83 \pm 1.32$ & $8.21 \pm 1.09$ & 1.923 & 0.06 & $7.27 \pm 0.91$ & $7.52 \pm 1.20$ & -0.934 & 0.35 \\
\hline $\begin{array}{l}\text { CMJ } \\
(\mathrm{cm})\end{array}$ & $24.71 \pm 4.49$ & $25.34 \pm 4.32$ & -0.526 & 0.60 & $26.57 \pm 4.49$ & $24.68 \pm 8.28$ & 0.987 & 0.33 \\
\hline $\mathrm{L} \mathrm{J}(\mathrm{cm})$ & $114.95 \pm 13.97$ & $117.10 \pm 16.32$ & -0.585 & 0.56 & $122.62 \pm 15.36$ & $117.18 \pm 20.44$ & 1.187 & 0.24 \\
\hline
\end{tabular}

Legend: $\mathrm{E}$ - experimental group; K- control group; SD-standard deviation; $\mathrm{t}$ - result of $\mathrm{t}$-test; $p$ - significance of difference

Table 2 shows differences in the achieved results between the initial and final measurement in both groups. These results show that the experimental group showed improvement in all tests, while the control group showed improvement in all coordination tests and in one agility test (LAT).

Table 2. Testing differences between the initial and final measurement ( $t$-test for dependent samples)

\begin{tabular}{|c|c|c|c|c|c|c|c|c|c|c|}
\hline \multirow{2}{*}{ Tests } & \multicolumn{4}{|c|}{ Experimental group } & \multicolumn{5}{c|}{ Control group } \\
\cline { 2 - 12 } & MeanD \pm SD & SEM & $\mathrm{t}$ & $p$ & ES & MeanD \pm SD & SEM & $t$ & $p$ & ES \\
\hline 20Y (sec) & $0.33 \pm 0.53$ & 0.09 & 3.683 & $\mathbf{0 . 0 0 1}$ & -0.50 & $0.04 \pm 0.83$ & 0.18 & 0.212 & 0.834 & 0.26 \\
\hline LAT (sec) & $1.29 \pm 0.91$ & 0.16 & 8.277 & $\mathbf{0 . 0 0 0}$ & -0.92 & $1.24 \pm 1.61$ & 0.32 & 3.854 & $\mathbf{0 . 0 0 1}$ & -0.69 \\
\hline PiP (sec) & $1.18 \pm 2.74$ & 0.52 & 2.274 & $\mathbf{0 . 0 3 1}$ & -0.29 & $1.75 \pm 2.72$ & 0.57 & 3.083 & $\mathbf{0 . 0 0 5}$ & -0.46 \\
\hline OuV (sec) & $1.20 \pm 1.08$ & 0.19 & 6.32 & $\mathbf{0 . 0 0 0}$ & -0.75 & $1.06 \pm 1.29$ & 0.27 & 3.956 & $\mathbf{0 . 0 0 1}$ & -0.60 \\
\hline OsS (sec) & $1.52 \pm 0.90$ & 0.16 & 9.586 & $\mathbf{0 . 0 0 0}$ & -1.18 & $0.67 \pm 0.81$ & 0.17 & 3.877 & $\mathbf{0 . 0 0 1}$ & -0.63 \\
\hline CMJ (cm) & $-2.17 \pm 2.82$ & 0.67 & -3.264 & $\mathbf{0 . 0 0 5}$ & 0.41 & $2.03 \pm 6.51$ & 1.45 & 1.395 & 0.179 & -0.15 \\
\hline L J (cm) & $-8.26 \pm 11.80$ & 1.91 & -4.319 & $\mathbf{0 . 0 0 0}$ & 0.55 & $-1.00 \pm 17.86$ & 3.44 & -0.291 & 0.773 & 0.00 \\
\hline
\end{tabular}

Legend: MeanD - arithmetic mean of the difference between the initial and final measurement; SD-standard deviation; SEM- standard error; $\mathrm{t}$ - result of $\mathrm{t}$-test; $p$ - significance of difference; ES-effect size

By comparing the results between the experimental and the control group in the final measurement (Table 1), it was determined that there are differences between results only in agility tests.

\section{DISCUSSION}

Test results from the initial measurement show that the control and the experimental group do not differ in any of the observed abilities, and that the differences obtained at the final measurement can be attributed to the influence of the experimental factor.
By observing results between the initial and the final measurement, it can be noted that the experimental group achieved improvement in all tests, while the control group made improvement in coordination tests and one agility test. Based on such results, it can be concluded that the rhythmic gymnastics training itself was sufficient as a stimulus for coordination improvement, as expected, given that rhythmic gymnastics belongs to sports in which results depend largely on the development of this ability. By comparing the results between experimental and control group at the final measurement, there are no differences between them at the final meas- 
urement, so that the improvement in coordination cannot be attributed to influence of proprioceptive training. According to results of an earlier study, in some coordination tests the authors found the improvement under the influence of proprioceptive training, but not in all tests; and the study was done on the sample of respondents of both genders, from 15 to 19 years of age (Lukić, 2010).

Agility, i.e., a segment of this ability which relates to the speed of movement direction change (Sheppard \& Young, 2006), showed the tendency of improvement under the influence of proprioceptive training. Such findings are in accordance with the results of Yaggie and Campbell (2006), and partially with the results of Šalaj et al. (2007), who found significant improvement in this ability under the influence of proprioceptive training in 20-yard test. Cressey et al. (2007) did not find a significant agility improvement under the influence of this training, and the reason for it may be the specific sample of soccer players, who are well known for a highly developed agility. A possible future study should assess the influence of proprioceptive training on this ability in children of both genders and in different periods of development.

In explosive strength tests, the experimental group showed improvement, while progress was not recorded in the control group. The comparison of the results from the final measurement points to the fact that the proprioceptive training had no positive influence on development of this ability. On the other hand, it should be understood that the experimental group had slightly weaker results on the initial measurement, but also slightly better results at the final measurement. This leads to the conclusion that the rhythmic gymnastics training in combination with proprioceptive explosive strength training may significantly improve the explosive strength of legs in girls aged 7-9. Previous studies, conducted on adults and with the use of the same tests, are in favour of positive influence of proprioceptive training on the explosive leg strength (Cressey et al., 2007; Granacher et al., 2010). Besides, a sensitive period for the explosive strength development is the period between the age of 10 and 12 (Гужаловский, 1984, Drabik, 1996), when a greater reaction of the child's organism to these stimuli can be expected. All the above should be taken into account and investigate the influence of this training on the explosive strength of legs in children of different age, including the sample of children of both genders, in some future studies.

\section{CONCLUSION}

Based on the presented results and the discussion it can be clearly concluded that the proprioceptive training has a positive impact on the development of agility in girls aged 7-9, while this type of training proved to be an insufficient stimulus for development of coordination. In combination with the rhythmic gymnastics training, proprioceptive trainings have positive effects on the explosive strength of legs in girls of this age. The development of the observed motor abilities under the influence of proprioceptive training in children should be additionally examined, by including into the study children of both genders and different age.

\section{Acknowledgement:}

Design of this stydy was presented at the international conference "Anthropological and theoantropological view of physical activity from Constantine the Great to the present", Kopaonik, Serbia, 22-25. March 2017.

The paper is a part of the research done within the project of the Ministry of Education, Science and Technological Development of Republic of Serbia: Effects of applied physical activity in locomotion, metabolic, psychosocial and educational status of the population of R. Serbia. No. 47015, extended cycle of scientific projects 2011-2018. 


\section{REFERENCES}

1. Bernier, J.N., \& Perrin, D.H. (1998). Effect of coordination training on proprioception of the functionally unstable ankle. Journal of Orthopaedic \& Sports Physical Therapy, 27(4), 264-275.

2. Cressey, E. M., West, C. A., Tiberio, D. P., Kraemer, W. J., \&Maresh, C. M. (2007). The effects of ten weeks of lower-body unstable surface training on markers of athletic performance. The Journal of Strength \& Conditioning Research, 21(2), 561-567.

3. Dobrijević, S., Moskovljević, L., \& Dabović, M. (2016). The influence of proprioceptive training on young rhythmic gymnasts balance. Facta Universitatis, Series: Physical Education and Sport, 247-255.

4. Drabik, J. (1996). Children and Sports Training. Island Point, VT: Stadium Publishing Company.

5. Elis, E., \& Rosenbaum, D. (2001). A multi-station proprioceptive exercise program in patients with ankle instability. Medicine \& Science in Sport \& Exercise, 33(12), 1991-1998.

6. Eils, E., Schröter, R., Schröder, M., Gerss, J., \& Rosenbaum, D. (2010). Multistation proprioceptive exercise program prevents ankle injures in basketball. Medicine \& Science in Sport \& Exercise, 42(11), 2098-2105.

7. Enoksen, E., Tonnessen, E., \& Shalfawi, S. (2009). Validity and reliability of the Newtest Power timer 300-series ${ }^{\circledast}$ testing system. Journal of sports sciences, 27(1), 77-84.

8. EUROPEAN TEST OF PHYSICALFITNESS, (1988), Council of Europe, Rome.

9. Hoffman, M., \& Payne, V.G. (1995). The effects of proprioceptive ankle disk training on healthysubjects. Journal of Orthopaedic \& Sports Physical Therapy, 21(2), 90-93.

10. Harris, T., \& Dudley, G. (2000). Neuromuscular Anatomy and Adaptations to Conditioning. Baechle (pp. 15-25). TR \& Earle, RW (Eds.) National Strength and Conditioning Association (2nd) edition.

11. Gauffin, H., Tropp, H., \& Odenrick, P. (1988). Effects of ankle disc training on postural control with functional instability of the ankle joint. International Journal of Sports Medicine, 9(2), 141-144.

12. Gioftsidou, A., Malliou, P., Pafis, G., Beneka, A., Godolias, G., \& Maganaris, C. N. (2006). The effects of socce rtraining and timing of balance training on balance ability. European Journal of Applied Physiology, 96(6), 659-664.

13. Granacher, U., Gollhofer, A., \& Kriemler, S. (2010). Effects of balance training on postural sway, leg extensor strength, and jumping height in adolescents. Research quarterly for exercise and sport, 81(3), 245-251.

14. Gruber, M., \& Gollhofer, A. (2004). Impact of sensori motor training on the rate of force development and neural activation. European journal of applied physiology, 92(1-2), 98-105.

15. Гужаловский, А.А. (1984): Проблема критических периодов онтогенеза и ее значение для теории и практики физического воспитания. [The problem of ontogeny critical periods and its significance for the theory and practice of physical education. In Russian]. Физкультура и cnopm, C. 211-224.

16. Irrgang, J.J., Whitney, S.L., \& Cox, E.D. (1994). Balance and proprioceptive training for rehabilitation of the lower extremity. Journal of Sport Rehabilitation, 3(1), 68-83.

17. Jukić, I., Milanović, L., Šimek, S., Nakić, J., \& Komes, Z. (2003). Metodika proprioceptivnog treninga na balans pločama. [Methods of proprioceptive training on balance plates. In Croatian] Kondicijski trening, 1(1), 55-59.

18. Kurelić, N., Momirović, K., Stojanović, M., Šturm, J., Radojević, Đ., \& Viskić-Štalec, N. (1975). Struktura $i$ razvoj morfoloških i motoričkih dimenzija omladine. [Structure and development of morphological and motoric dimensions of youth. In Serbo-Croatian]. Institut za naučna istraživanja Fakulteta za fizičko vaspitanje, Beograd.

19. Laskowski, E.R., Newcomer-Aney, K., \& Smith, J. (1997). Refining rehabilitation with proprioception training: Expediting return to play. The Physician and Sports medicine, 25(10).

20. Lephart, S.M., \& Fu, F.H. (2000). Proprioception and Neuromuscular Control and Joint Stability. Champaign, II: Human Kinetics.

21. Liu-Ambrose, T., Taunton, J.E., MacIntyre, D., McConkey, P., \& Khan, K.M. (2003). The effects of proprioceptive of strength training on the neuromuscular function of the ACL reconstructed knee: a randomized clinical trial. Scandinavian Journal of Medicine and Science in Sport, 13(2), 115-123. 
22. Lukić, A. (2010). Efekti proprioceptivnog treninga na razvijanje ravnoteže i poboljšanje tehnike izvođenja u sportskom plesu. $[\mathrm{PhD}$ thesis: The effects of proprioceptive training on developing the balance and improving the technique of performing in sports dancing. In Serbian]. Doktorska disertacija, Univerzitet u Banja Luci, Fakultet fizičkog vaspitnja i sporta, Banja Luka.

23. Metikoš, D., Hofman, E., Prot, F., Pintar, Ț., \&Oreb, G. (1989). Mjerenje bazičnih motoričkih dimenzija sportaša [Measurement of basic motor characteristics of athletes. In Croatian]. Zagreb, Faculty of Physical Culture University of Zagreb.

24. Milanović, L. (2003). 20 jardi - test za procjenu agilnosti. [20 yards - agility test. In Croatian]. Kondicijski trening, 1(1), 12-13.

25. Robbins, S., \&Waked, E. (1998). Factors associated with ankle injuries. Preventive measures. Sports Medicine, 25(1), 63-72.

26. Romero-Franco, N., Martínez-López, E., Lomas-Vega, R., Hita-Contreras, F., \&Martínez-Amat, A. (2012). Effects of proprioceptive training program on core stability and center of gravity control in sprinters. The Journal of Strength \& Conditioning Research, 26(8), 20712077.

27. Sheppard, J. M., \& Young, W. B. (2006). Agility literature review: Classifications, training and testing. Journal of sports sciences, 24(9), 919-932.

28. Sheth, P., Yu, B., Laskowski, E.R., \& An, K.N. (1997). Ankle disk training influences reaction times of selected muscle in a simulated ankle sprain. The American Journal of Sports Medicine, 25(4), 538-543.

29. Spencer, M., Dawson, B. Goodman, C., Dascombe, B., \& Bishop, D. (2008). Performance and metabolism in repeated sprint exercise: effect of recovery intensity. European Journal of Applied Physiology, 103, 545-552.

30. Šebić-Zuhrić, L., Rađo, I. i Bonacin, D. (2007). Efekti proprioceptivnog treninga na rezultate u specifičnim gibanjima ritmičke gimnastike. [Effects of proprioceptive training on results in specific movements of rhythmic gymnastics. In Croatian]Acta Kinesiologica, 1(2007) 1:30-37.

31. Šimek, S., Milanović, D., \& Jukić, I. (2008). The effects of proprioceptive training on jumping and agility performance. Kineziologija, 39(2), 131-141.

32. Vad, V., Hong, H. M., Zazzali, M., Agi, N., \& Basrai, D. (2002). Exercise recommendations in athletes with earlyo steoarthritis of the knee. Sports medicine, 32(11), 729-739.

33. Voight, M. L., \& Cook, G. (1996). Clinical application of closed kinetic chain exercise. Journal of Sport Rehabilitation, 5(1), 25-44.

34. Wester, J.U., Jespersen, S.M., Nielsen, K.D., \& Neumann, L. (1996). Wobble board training after partial sprains of the lateral ligaments of the ankle - a prospective randomized study. Journal of Orthopaedic and Sports Physical Therapy, 23(5), 332-336.

35. Wolf-Cvitak, J., Grčić-Zubčević, N., \& Dolančić, A. (2002). Kinesthetic perception in rhythmic gymnastics open vs. closed eye performance. In D. Milanović \& F. Prot (Eds.). Kinesiology - New Perspectives, Proceedings, 3rd International Scientific Conference. Opatija, 25-29 September, pp. 253-256. Zagreb: Faculty of Kinesiology, University of Zagreb.

36. Yaggie, J. A., \& Campbell, B. M. (2006). Effects of balance training on selected skills. The Journal of Strength \& Conditioning Research, 20(2), 422-428. 


\title{
EFECTOS DE LA APLICACIÓN DE ENTRENAMIENTO PROPIOCEPTIVO SOBRE LA FUERZA, AGILIDAD Y COORDINACIÓN DE JÓVENES GIMNASTAS RÍTMICAS
}

\begin{abstract}
Resumen
El objetivo de la presente investigación era examinar la influencia del entrenamiento sobre la fuerza explosiva, agilidad y coordinación de las niñas de 7-9 años de edad que se entrenan en gimnasia rítmica. Las mediciones se realizaron en una muestra de 74 niñas sanas. La muestra se ha dividido en dos grupos: el grupo experimental (43 niñas) y el grupo de control (31 niña). El grupo experimental aplicaba el entrenamiento propioceptivo en marco de sus entrenamientos regulares RG, en período de 12 semanas (24 entrenamientos). El grupo de control asistía solo a los entrenamientos de gimnasia rítmica. Para establecer los efectos del factor experimental sobre las capacidades motrices seguidas se utilizaron los test estandarizadas para valorar la fuerza, coordinación y agilidad. Todas las niñas examinadas fueron medidas antes de la aplicación del factor experimental (preprueba) y después de su terminación (postprueba). Para establecer la diferencia en los resultados alcanzados entre la medición inicial y final para cada grupo, se utilizó prueba-t para las muestras dependientes. Para establecer la diferencia entre grupos en la medición inicial y final se utilizó prueba-t para las muestras independientes. Por análisis de los resultados de la medición inicial y final se constató progreso en todos los atributos de las capacidades motrices seguidas en el grupo experimental. En las niñas examinadas en el grupo de control se notó progreso en el espacio de coordinación y agilidad. La prueba estadística de las diferencias de los resultados entre los grupos en la medición final demostró que la diferencia entre los grupos existe solo en el espacio de agilidad a favor del grupo experimental. Sobre la base de los resultados obtenidos se llegó a conclusión que la aplicación de entrenamiento propioceptivo en las niñas incluidas en el programa de gimnasia rítmica puede contribuir al aumento de los atributos motrices que tienen influencia en la agilidad, mientras que en el espacio de las demás capacidades motrices seguidas no se puede confirmar con seguridad que se ha notado progreso como resultado de la aplicación de entrenamiento propioceptivo.
\end{abstract}

Palabras claves: PROPIOCEPCION/ CAPACIDADES MOTRICES / GIMNASIA RÍTMICA / NIÑAS

Reacived: 16.10 .2017$.

Accepted: 20.03.2018. 


\title{
ЕФЕКТИ ПРИМЕНЕ ПРОПРИОЦЕПТИВНОГ ТРЕНИНГА НА СНАГУ, АГИЛНОСТ И КООРДИНАЦИЈУ МЛАДИХ РИТМИЧАРКИ
}

\author{
Слободанка М. Добријевић, Лидија Московљевић, Милош Марковић, Милинко Дабовић
}

Универзитет у Београду, Факултет спорта и физичког васпитања, Београд, Србија

\begin{abstract}
Сажетак
Циљ овог истраживања био је да се испита утицај проприоцептивног тренинга на експлозивну снагу, агилност и координацију девојчица узраста 7-9 година које тренирају ритмичку гимнастику. Мерења су спроведена на узорку од 74 здраве девојчице. Узорак је подељен у две групе: експерименталну (43 девојчице) и контролну (31 девојчица). Експериментална група је примењивала проприоцептивни тренинг у оквиру својих редовних тренинга РГ, у периоду од 12 недеља (24 тренинга). Контролна група је похађала само тренинге ритмичке гимнастике. Да би се утврдили ефекти експерименталног фактора на праћене моторичке способности коришћени су стандардизовани тестови за процену снаге, координације и агилности. Све испитанице мерене су пре почетка примене експерименталног фактора (претест) и након његовог завршетка (посттест). За утврђивање разлика у постигнутим резултатима између иницијалног и финалног мерења, за сваку од група, коришћен је $t$ -тест за зависне узорке. За утврђивање разлика између група на иницијалном и финалном мерењу коришћен je $\mathrm{t}$-тест за независне узорке. Анализом резултата иницијалног и финалног мерења констатован је напредак код свих праћених моторичких способности у експерименталној групи. Код испитаница у контролној групи забележен је напредак у простору координације и агилности. Статистичко тестирање разлика резултата између група у финалном мерењу показало је да разлике између група постоје само у простору агилности и то у корист експерименталне групе. На основу добијених резултата дошло се до закључка да примена проприоцептивног тренинга код девојчица укључених у програм ритмичке гимнастике може допринети прирасту моторичких способности које имају утицај на агилност, док се у простору преосталих праћених моторичких способности не може са сигурношћу тврдити да је забележен напредак као резултат примене проприоцептивног тренинга.
\end{abstract}

КљУЧНе речИ: ПРОПРИОЦЕПЦИЈА/ МОТОРИЧКЕ СПОСОБНОСТИ / РИТМИЧКА ГИМНАСТИКА / ДЕВОЈЧИЦЕ

\section{УВОД}

Моторичке способности налазе се у основи човекове локомиције, самим тиме оне су доминантан фактор његове ефикасности током физичке активности. Оне значајно утичу, како на биолошки, тако и на психолошки и социјални аспект човековог живота.

С обзиром на важност моторичких способности у постизању моторичке писмености, оне су често предмет истраживања. Стручњаци често истражују различите тренажне методе и врсте тренинга које могу допринети њиховом побољшању, што је од посебног значаја у периоду рас- та и развоја. Метод тренинга, чији утицај и веза са различитим моторичким способностима, који још увек није у потпуности истражен, је проприоцептивни тренинг. Овај тип тренинга је усмерен на изазивање адекватног неуромишићног одговора након стимулације проприоцептора. Примена овог метода, у првом реду доприноси стабилности активних и пасивних стабилизатора око зглобова, подстиче елементе пасивне и активне равнотеже и стабилности читавог тела, а затим и прецизнијем и ефикаснијем извођењу свих врста кретања. Овим методом се усавршава контрактилност саме мишићне ћелије. Најзначајније за то су дражи настале побуђивањем интрафузалних 
мишићних влакана, такозваних „мишићних вретена“, Голџијевих тетивних органа и Пачинијевих телашаца. Ови рецептори реагују на промене у напетости и дужини мишића и тетива, на брзину ових промена, као и на промене положаја тела и делова тела (Harris \& Dudley 2000; Lephart \& Fu 2000). Раздражења ових рецептора преносе се аферентним путевима до нижих или виших нивоа централног нервног система, како би се правовременом активацијом одговарајућих моторних јединица омогућило одржавање стабилности тела током статичких и динамичких активности (Laskowski, Newcomer-Aney, \&Smith, 1997). Проприоцептивни тренинг подстиче, у координационом смислу ефикасније извођење покрета и кретања, док у енергетском смислу има утцај на ефикасност мишићног рада.

Проприоцептивни тренинг је примењиван најпре у рехабилитацији, најчешће након повреда скочног зглоба и колена. Утврђено је да се његовом применом побољшава функционална стабилност зглобова, доприноси побољшању клиничке слике код нарушеног постуралног статуса и значајно смањује фреквенције поновног повређивања (Irrgang et al, 1994; Wester et al, 1996; Bernier \& Perrin, 1998; Elis \& Rosenbaum, 2001; Vad et al, 2002; LiuAmbrose, et al, 2003). Резултати истрживања у простору рехабилитације обезбедили су довољно научних верификација за примену овог метода у спорту. Велики број аутора истиче да побољшање неуро-мишићног одговора на раздражење кинестетичких рецептора, може бити кључни фактор у ефикасном смањењу ризика од повреде (Gauffin, Tropp \& Odenrick, 1988; Sheth et al, 1997; Robbins \& Waked, 1998; Eils et al, 2010). Импулси свесних покрета који су иницирани у кори мозга спори су да би спречили повреду у екстремним ситуацијама, па се претпоставља да путем „тренинга“" спиналних рефлекса које је могуће вршити и проприоцептивним тренингом, долази до брже и правовремене активације мишића који стабилизују примарне зглобове (Laskowski et al, 1997).

Код здравих особа позитивни ефекти овог тренинга огледају се првенствено у побољшању одржавања равнотеже, односно у смањењу постуралних осцилација (Hoffman \& Payne, 1995), док његов утицај на друге моторичке способности није у потпуности истражен.

Предмет истраживања великог боја аутора је утицај проприоцептивог тренинга на равноте- жу и сви истичу његов позитиван ефекат на ову способност, како код одраслих особа (Gioftsidou et al, 2006; Yaggie \& Campbell, 2006; Granacher, Gollhofer \& Kriemler, 2010; Romero-Franco et al, 2012), тако и код деце (Добријевић, Московљевић и Дабовић, 2016). Када је у питању јачина, различити аутори се слажу да примена проприоцептивног тренинга нема утицаја на ову моторичку способност, али да има позитиван утицај на брзину прираста силе (Gruber \& Gollhofer, 2004; Granacher et al, 2010).

Налази аутора по питању утицаја проприоцептивног тренинга на експлозивну снагу и агилност су различити, често су и супростављени (Yaggie \& Campbell, 2006; Cressey et al, 2007; Šimek, Milanović \& Jukić, 2008; Granacher, et al, 2010). Мало је података о утицају проприоцептивног тренинга на координацију (Lukić, 2010), a постојеће верификације науке у пракси не пружају довољно јасан одговор на ово питање. Добријевић и сарадници (2016) истичу да примена проприоцептивног тренинга код младих ритмичарки може значајно допринети развоју равнотеже, као једне од круцијалних моторичких способности за успех у овој спортској грани. Неки други аутори који су истраживали утицај проприоцептивног тренинга на специфичну спортску технику (Wolf-Cvitak et al, 2002; ŠebićZuhrić, Rađo i Bonacin, 2007), наводе да ослањајући се на кинестетички осећај, учење одређених покрета у спортовима, каква је и ритмичка гимнастика, може значајно да убрза учење вештина, те да проприоцептивни тренинг представља значајно средство за овладавање специфичном техником, па и оном која се налази у у ритмичкој гимнастици.

Дакле, предмет овог рада је утицај тренинга проприоцепције на моторичке способности девојчица узраста 7-9 година. Циљ овог рада био је да се испита утицај проприоцептивног тренинга на одабране моторичке способности (агилност, координацију и снагу) младих ритмичарки.

\section{МЕТОД РАДА}

Ово истраживање представља лонгитудиналну студију, која је спроведена на узорку девојчица које ритмичку гимнастику тренирају 1-2 године. Предмет рада је дефинисан унутар ефеката про- 
приоцептивног тренинга на моторичке способности девојчица (агилност, координацију и експлозивну снагу ногу) у развојном периоду током кога учествују у организованом тренингу ритмичке гимнастике.

\section{Испитаници}

Узорак испитаника чиниле су 74 здраве девојчице, које тренирају ритмичку гимнастику у Гимнастичком клубу „Ин” из Београда. Све девојчице су укључене у овај програм вежбања 1-2 године, а тренирају два пута недељно у трајању од 60 минута. Оне су методом случајног узорка подељене у две групе, експерименталну (Е) - 43 девојчице, узраста $8.1 \pm 0.7$ и контролну, узраста $7.9 \pm 0.8$ (К) - 31 девојчица. Девојчице и њихови родитељи су информисани о свим детаљима студије, и за учешће девојчица у истраживању родитељи су дали писмени пристанак.

\section{Експериментални протокол}

Све испитанице су тестиране пре почетка експеримента (иницијално мерење-Т1) и након 12 недеља примене експерименталног третмана (финално мерење - Т2). Узорак варијабли обухватао је две варијабле за процену агилности, три за процену координације и две за процену експлозивне снаге ногу. Све варијабле мерене су тестовима који су стандардизовани и чија је валидност и поузданост раније потврђена, и то:

- агилност - тест 20 јарди (20 Y) (Milanović, 2003) и тест латералне агилности- кораци у страну (LAT) (Metikoš et al, 1989),

- координација -окретност у ваздуху (OuV) (Курелић, и сар. 1975), осмица са сагињањем и прескакањем (OsS) (Eurofit, 1988), прескакање и провлачење (PiP) - (Metikoš et al, 1989),

- експлозивна снага мишића ногу - скок у вис из почучња (countermovementjump, СМJ) (Enoksen, Tonnessen \& Shalfawi, 2009) и скок у даљ из места (LJ) (Eurofit, 1988).

\section{Мерења}

Испитанице су биле упознате са протоколом теста пре почетка мерења. Свака испитаница је приликом сваког појединачног теста имала један пробни покушај, затим су изведена два мерења, а бољи резултат је издвојен за анализу. Паузе између покушаја биле су 3-5 минута, што је било довољно за опоравак испитаница и избегавање евентуалног утицаја замора у следећем извођењу (Spencer, et al, 2008). Испитаницама су пре сваког теста дате инструкције да што брже заврше постављен задатак, у тестовима координације и агилности, док су у тестовима експлозивне снаге добиле инструкције да скоче што више (CMJ), односно што даље (LJ). Сва тестирања су спроведена у преподневним часовима, у дворани Спортског центра "Нови Београд”. Испитанице су током тестирања носиле спортску гардеробу.

Tecū 20 јарgu (20 Y) се изводи трчањем на 20 јарди максималном брзином са једним окретом за $90^{\circ}$ и два окрета за $180^{\circ}$. Ипитаница је у почетном положају окренута боком у правцу кретања. Полази се са средине; прво трчи до десног стуба$(5 \mathrm{y}=4.55 \mathrm{~m})$, затим до левог стуба $(10 \mathrm{y}=9.1 \mathrm{~m})$, и на крају до средњег $(5 \mathrm{y}=4.55 \mathrm{~m})$. Тести лайералне аіилностии (LAT) изводи се на кретањем странце (докорацима) максималном брзином и то на обележеној стази дужине $4 \mathrm{~m}$. Испитаница стоји иза стартне линије, боком окренута правцу кретања. На знак мериоца започиње кретање, а стазу прелази укупно 6 пута $(6 \mathrm{x} 4 \mathrm{~m})$, не мењајући оријентацију у простору (мења само смер кретања).

Тести йровлачене и йрескакане (РіР) изводи се у простору дужине 7,5m, где је на сваких 1,5m постављен по један сегмент шведског сандука, укупно њих четири, а 1,5m иза последњег сегмента налази се линија окретишта. Испитаница стоји иза стартне линије и на знак мериоца започиње кретање. Наизменично прескаче и провлачи се кроз сегменте шведског сандука, тако што у оба правца први сегмент прескаче, кроз други се провлачи, итд.

Окрейности у вазgуху (OuV) изводи се тако што испитаница започиње кретање из почетног положаја, седећи на 4 медицинке, леђима окренута правцу кретања. На знак мериоца треба што брже да изведе колут назад, усправи се и изведе колут напред преко медицинки, не додирујући их. Након колута напред окреће се за $180^{\circ}$ и длановима дотакне све 4 медицинке.

"Осмица" са ировлачеюем и ирескакағем $(O s S)$ изводи се кретањем између три сталка, који су постављени у линији на растојању од 2,5 m. Између сталака је разапета еластична трака, и то узмеђу првог и другог у висини кука, а између другог и трећег у висини колена испитаника. 
Испитаница треба за што краће време да обиђе сталке сагињући се сваки пут испод еластичне траке која је постављена у висини кука и прескачући еластичну траку потављену у висини колена.

Скок удаль из местиа (LJ) се изводи на равној, не клизавој површини на којој је обележено скакалиште и место за одраз. Задатак је да суножним одсоком и доскоком скочи што даље, а мери се растојање од линије одскока до места где испитаник петом оствари контакт са тлом. Скок у вис са почучњем (countermovementjump, CMJ) изводио се на контактној подлози (Newtest Power timer, 300-series). Испитаница стоји усправно на подлози, са стопалима у ширини кукова. Затим изводи суножни скок у вис са почучњем и замахом рукама.

\section{Експериментални програм}

\section{проприоцептивног модела тренинга}

У периоду од 12 недеља (24 тренинга), експериментална група је била подвргнута проприоцептивном тренингу, пре својих редовних тренинга ритмичке гимнастике, док је контролна група за то време похађала само своје редовне тренинге. Тренинг проприоцепције је почињао 15 минута пре редовног тренинга ритмичке гимнастике, а једним делом се настављао и током тренинга ритмичке гимнастике. Оваква организација је примењивана због изједначавања обима рада у експерименталној и контролној групи, што је постизано с обзиром на то да су се у проприоцептивном тренингу време активног вежбања и одмора смењивали у једнаким временским интервалима. Програм проприоцептивног тренинга је реализован помоћу реквизита и справа: Т-даска, даска са полулоптом, даска са ваљком, лопте за пилатес, ниска греда, мекане струњаче. На проприоцептивним даскама испитаници су имали задатак да у нестабилним условима што дуже одрже равнотежни положај, греда је коришћена за извођење задатака на малој површини ослонца, а струњаче за стимулацију проприоцептора променом квалитета подлоге (нпр. кретање на мекој, па на тврдој подлози). Један број вежби био је извођен са отвореним и затвореним очима, на обе или једној нози, а у каснијим фазама трајања експерименталног фактора укључена је и спе- цифична техника ритмичке гимнастике, као што су: ठалансирање лопте, вртење обруча или вијаче, избацивања и хватања..., а све са циљем усложњавања задатака и повећања стимулације проприоцептора. Тренинг проприоцепције подразумевао је загревање у трајању око 5 минута и главну фазу тренинга организовану по методу станица. На сваком тренингу испитанице су имале 3 задатка, које су изводиле у 3 серије, са једнаким временом вежठања и опоравка између серија (Jukić et al, 2003). Девојчице су најчешће биле организоване у парове, тако да док једна изводи вежбу, друга одмара. Садржаји овог програма реализовани су на почетку тренинга, а укупно трајање активне фазе проприоцептивног тренинга по испитанику није трајало више од 10 минута, како не би дошло до нервно-мишићног замора. Посебна пажња била је усмерена на концентрацију испитаница при извођењу задатака, јер се на тај начин повећава економичност протока чулних информација у централном нервном систему (Voight, \& Cook, 1996), што доприноси већој ефикасности вежठања

\section{Статистичка обрада података}

Подаци прикупљени у овом истраживању сређени су и обрађени у статистичким процедурама прогама Мајкрософт ексел, верзија 15 и SPSS 22.0. Из простора дескриптивне статистике, за сваку варијаблу, одређена је аритметичка средина (Mean), стандардна девијација (SD) и стандардна грешка мерења (SEM). За тестирање нормалности расподеле резултата коришћен је Шапиро-Вилков тест. Из простора компаративне статистике, коришћен је т-тест за независне узорке, како би се утврдило постојање или одсуство разлике у резултатима између контролне и експерименталне групе, посебно за иницијално и финално мерење. Израчунат је т-тест за зависне узорке ради утврђивања разлика у резултатима између иницијалног и финалног мерења.

\section{РЕЗУЛТАТИ}

Тестирање разлика између група на иницијалном мерењу (Табела 1) показало је да се оне не разликују ни у једном од примењених тестова. 


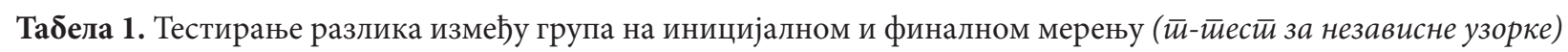

\begin{tabular}{|c|c|c|c|c|c|c|c|c|}
\hline \multicolumn{5}{|c|}{ Иницијално мерење } & \multicolumn{4}{|c|}{ Финално мерење } \\
\hline \multirow{2}{*}{ Тест } & Е група & К група & \multirow{2}{*}{$\mathbf{t}$} & \multirow{2}{*}{$p$} & Е група & К група & \multirow{2}{*}{$\mathbf{t}$} & \multirow{2}{*}{$p$} \\
\hline & Mean \pm SD & Mean \pm SD & & & Mean \pm SD & Mean \pm SD & & \\
\hline $20 \mathrm{Y}(\mathrm{sec})$ & $7.94 \pm 0.64$ & $8.16 \pm 0.52$ & -1.496 & 0.14 & $7.62 \pm 0.66$ & $8.30 \pm 1.04$ & -2.922 & 0.01 \\
\hline LAT (sec) & $16.26 \pm 1.45$ & $16.88 \pm 1.60$ & -1.647 & 0.10 & $14.93 \pm 1.37$ & $15.77 \pm 1.86$ & -2.041 & 0.05 \\
\hline $\mathbf{P i P}(\mathrm{sec})$ & $19.36 \pm 4.45$ & $18.75 \pm 4.03$ & 0.562 & 0.58 & $18.07 \pm 4.08$ & $16.91 \pm 3.28$ & 1.153 & 0.25 \\
\hline $\mathbf{O u V}(\mathrm{sec})$ & $7.38 \pm 1.55$ & $7.69 \pm 1.61$ & -0.771 & 0.44 & $6.22 \pm 1.21$ & $6.72 \pm 1.22$ & -1.564 & 0.12 \\
\hline OsS (sec) & $8.83 \pm 1.32$ & $8.21 \pm 1.09$ & 1.923 & 0.06 & $7.27 \pm 0.91$ & $7.52 \pm 1.20$ & -0.934 & 0.35 \\
\hline $\mathbf{C M J}(\mathrm{cm})$ & $24.71 \pm 4.49$ & $25.34 \pm 4.32$ & -0.526 & 0.60 & $26.57 \pm 4.49$ & $24.68 \pm 8.28$ & 0.987 & 0.33 \\
\hline $\mathbf{L} \mathbf{J}(\mathrm{cm})$ & $114.95 \pm 13.97$ & $117.10 \pm 16.32$ & -0.585 & 0.56 & $122.62 \pm 15.36$ & $117.18 \pm 20.44$ & 1.187 & 0.24 \\
\hline
\end{tabular}

Легенда: E - експериментална група; К- контролна група; Mean -аритметичка средина; SD-стандардна девијација; $\mathrm{t}$ - резултат т-теста; $p$ - значајност разлике

У табели 2 приказане су разлике у постигнутим резултатима између иницијалног и финалног мерења код обе групе. Ови резултати указују да је експериментална група остварила напредак у мереним способностима, док је код контролне групе напредак забележен у простору координације (на свим тестовима) и једном тесту агилности (LAT).

Табела 2. Тестирање разлика између иницијалног и финалног мерења ( $\bar{u}-\bar{u} е с \bar{u}$ за зависне узорке)

\begin{tabular}{|c|c|c|c|c|c|c|c|c|c|c|}
\hline \multirow{2}{*}{ Tест } & \multicolumn{4}{|c|}{ Експериментална група } & \multicolumn{4}{c|}{ Контролна група } \\
\cline { 2 - 11 } & MeanD \pm SD & SEM & $\mathrm{t}$ & $p$ & $\mathrm{ES}$ & MeanD \pm SD & SEM & $\mathrm{t}$ & $p$ & $\mathrm{ES}$ \\
\hline $\mathbf{2 0 Y}(\mathrm{sec})$ & $0.33 \pm 0.53$ & 0.09 & 3.683 & $\mathbf{0 . 0 0 1}$ & -0.50 & $0.04 \pm 0.83$ & 0.18 & 0.212 & 0.834 & 0.26 \\
\hline LAT $(\mathrm{sec})$ & $1.29 \pm 0.91$ & 0.16 & 8.277 & $\mathbf{0 . 0 0 0}$ & -0.92 & $1.24 \pm 1.61$ & 0.32 & 3.854 & $\mathbf{0 . 0 0 1}$ & -0.69 \\
\hline PiP $(\mathrm{sec})$ & $1.18 \pm 2.74$ & 0.52 & 2.274 & $\mathbf{0 . 0 3 1}$ & -0.29 & $1.75 \pm 2.72$ & 0.57 & 3.083 & $\mathbf{0 . 0 0 5}$ & -0.46 \\
\hline OuV $(\mathrm{sec})$ & $1.20 \pm 1.08$ & 0.19 & 6.32 & $\mathbf{0 . 0 0 0}$ & -0.75 & $1.06 \pm 1.29$ & 0.27 & 3.956 & $\mathbf{0 . 0 0 1}$ & -0.60 \\
\hline OsS $(\mathrm{sec})$ & $1.52 \pm 0.90$ & 0.16 & 9.586 & $\mathbf{0 . 0 0 0}$ & -1.18 & $0.67 \pm 0.81$ & 0.17 & 3.877 & $\mathbf{0 . 0 0 1}$ & -0.63 \\
\hline CMJ $(\mathrm{cm})$ & $-2.17 \pm 2.82$ & 0.67 & -3.264 & $\mathbf{0 . 0 0 5}$ & 0.41 & $2.03 \pm 6.51$ & 1.45 & 1.395 & 0.179 & -0.15 \\
\hline L J $(\mathrm{cm})$ & $-8.26 \pm 11.80$ & 1.91 & -4.319 & $\mathbf{0 . 0 0 0}$ & 0.55 & $-1.00 \pm 17.86$ & 3.44 & -0.291 & 0.773 & 0.00 \\
\hline
\end{tabular}

Легенда: MeanD - аритметичка сердина разлике између иницијалног и финалног мерења; SD- стандардна девијација; SEM- стандардна грешка; $\mathrm{t}$ - резултат т-теста; $p$ - значајност разлике; ES-ефекат величине

Поређењем резултата између експерименталне и контролне групе на финалном мерењу (табела 1), утврђено је да разлике у резултатима постоје само у тестовима агилности.

\section{ДискУСИЈА}

Резултати иницијалног мерења показују да се контролна и експериментална група нису разликовале ни у једној од посматраних способности, сходно чему се разлике добијене на финалном мерењу могу приписати утицају експерименталног фактора.

Посматрањем разлика иницијалног и финалног мерења, уочава се да је експериментална група остварила напредак у свим тестовима, док је контролна група напредовала у тестовима координације и једном тесту агилности. Може се претпоставити да је сам тренинг ритмичке гимнастике био довољан стимулус за побољшање способности координације у контролној групи. Упоређивањем резултата између експерименталне и контролне групе на финалном мерењу, у тестовима координације нема разлика међу њима, тако да се напредак у координацији, у овом протоколу, не може приписати утицају проприоцептивног тренинга. Према резултатима једног ранијег истраживања у појединим тестовима координације, аутори су пронашли напредак под утицајем проприоцептивног тренинга, али не у свим тестовима, с’ том 
ограничавајућом чињеницом у закључивању на узорак овог истраживања, а то је да је истраживање извршено на узорку испитаника оба пола, узраста 15 до 19 година (Лукић, 2010).

Агилност, односно један сегмент ове способности, који се односи на брзину промене правца кретања (Sheppard \& Young, 2006), показала је тенденцију напретка под утицајем експерименталног фактора. Овакви налази су у сагласности са резултатима Јагија и Кампбела (Yaggie, Campbell, 2006), а делом и са резултатима Шимек и сарадника (2008), који су значајан напредак у овој способности, под утицајем проприоцептивног тренинга проценили на основу резултата на тесту 20 јарди. Креси и сарадници (Cressey et al, 2007) нису утврдили значајан напредак у агилности под утицајем овог тренинга, а разлог томе може бити и специфичан ток тренажних адаптација фудбалера, за које је карактеристичан висок ниво развијености ове способности или недовољан стимулус примењеног тренинга. У некој наредној студији требало би проверити утицај проприоцептивног тренинга на ову способност код деце оба пола и у различитом развојним периодима.

На основу резултата на тестовима експлозивне снаге експериментална група је показала напредак, док напредак није забележен у контролној групи. Поређење резултата финалног мерења, указује на то да сам проприоцептивни тренинг није имао утицај на развој ове способности. С друге стране, треба сагледати и чињеницу да је експериментална група имала незнатно слабије резултате на иницијалном, али и незнатно боље резултате на финалном мерењу. Ово наводи на закључак, да тренинг ритмичке гимнастике у комбинацији са проприоцептивним тренингом може бити средство за развој експлозивности мишића ногу код девојчица узраста 7-9 година. Претходне студије, које су извршене на одраслим особама, а коришћењем истих тестова, говоре у прилог позитивног утицаја проприоцептивног тренинга на експлозивну снагу ногу (Cressey et al, 2007; Granacher et al, 2010). Поред овога, сензитивни период за развој експлозивне снаге је период између 10. и 12. године (Гужаловский, 1984; Drabik, 1996), када се може очекивати и већа реакција дечјег организма на ове стимулусе. Све горе наведено би требало узети у обизир, па у некој наредној студи- ји испитати утицај овог тренинга на експлозивну снагу ногу код деце различитог узраста, укључујући при том у узорак децу оба пола.

\section{ЗАКЉУЧАК}

На основу презентованих резултата и дискусије јасно се може закључити да примењени проприоцептивни тренинг позитивно утиче на развој агилности код девојчица узраста 7-9 година, док се за развој координације овај тип тренинга показао као недовољан стимулативан. У комбинацији са тренингом ритмичке гимнастике, примењени проприоцептивни тренинг даје позитивне ефекте на експлозивну снагу ногу код девојчица овог узраста. Развој посматраних моторичких способности под утицајем проприоцептивног тренинга код деце могао би се додатно испитати, укључивањем деце оба пола и различитог узраста у узорак.

\section{НАПОМЕНА:}

Приказ истраживања је излаган на Међународној научној конференцији „Антрополошки и теоантрополошки поглед на физичке активности од Константина Великог до данас“, Копаоник, Србија, 22-25.03.2017. год.

Овај рад је део истраживања у оквиру пројекта „Ефекти примењене физичке активности на локомоторни, метаболички, психосоцијални и васпитни статус популације Републике Србије“ ев. број III47015 који финансира Министарство за науку и технолошки развој - продужен циклус научних пројеката 2011-2018. 


\section{ЛИТЕРАТУРА}

1. Bernier, J.N., \& Perrin, D.H. (1998). Effect of coordination training on proprioception of the functionally unstable ankle. Journal of Orthopaedic \& Sports Physical Therapy, 27(4), 264-275.

2. Cressey, E. M., West, C. A., Tiberio, D. P., Kraemer, W. J., \&Maresh, C. M. (2007). The effects of ten weeks of lower-body unstable surface training on markers of athletic performance. The Journal of Strength \& Conditioning Research, 21(2), 561-567.

3. Dobrijević, S., Moskovljević, L., \& Dabović, M. (2016). The influence of proprioceptive training on young rhythmic gymnasts balance. Facta Universitatis, Series: Physical Education and Sport, 247-255.

4. Drabik, J. (1996). Children and Sports Training. Island Point, VT: Stadium Publishing Company.

5. Elis, E., \& Rosenbaum, D. (2001). A multi-station proprioceptive exercise program in patients with ankle instability. Medicine \& Science in Sport \& Exercise, 33(12), 1991-1998.

6. Eils, E., Schröter, R., Schröder, M., Gerss, J., \& Rosenbaum, D. (2010). Multistation proprioceptive exercise program prevents ankle injures in basketball. Medicine \& Science in Sport \& Exercise, 42(11), 2098-2105.

7. Enoksen, E., Tonnessen, E., \& Shalfawi, S. (2009). Validity and reliability of the Newtest Power timer 300-series ${ }^{\circledast}$ testing system. Journal of sports sciences, 27(1), 77-84.

8. EUROPEAN TEST OF PHYSICALFITNESS, (1988), Council of Europe, Rome.

9. Hoffman, M., \& Payne, V.G. (1995). The effects of proprioceptive ankle disk training on healthysubjects. Journal of Orthopaedic \& Sports Physical Therapy, 21(2), 90-93.

10. Harris, T., \& Dudley, G. (2000). Neuromuscular Anatomy and Adaptations to Conditioning. Baechle (pp. 15-25). TR \& Earle, RW (Eds.) National Strength and Conditioning Association (2nd) edition.

11. Gauffin, H., Tropp, H., \& Odenrick, P. (1988). Effects of ankle disc training on postural control with functional instability of the ankle joint. International Journal of Sports Medicine, 9(2), 141-144.

12. Gioftsidou, A., Malliou, P., Pafis, G., Beneka, A., Godolias, G., \& Maganaris, C. N. (2006). The effects of socce rtraining and timing of balance training on balance ability. European Journal of Applied Physiology, 96(6), 659-664.

13. Granacher, U., Gollhofer, A., \& Kriemler, S. (2010). Effects of balance training on postural sway, leg extensor strength, and jumping height in adolescents. Research quarterly for exercise and sport, 81(3), 245-251.

14. Gruber, M., \& Gollhofer, A. (2004). Impact of sensori motor training on the rate of force development and neural activation. European journal of applied physiology, 92(1-2), 98-105.

15. Гужаловский, А.А. (1984): Проблема критических периодов онтогенеза и ее значение для теории и практики физического воспитания. Физкультура и спорт, С. 211-224.

16. Irrgang, J.J., Whitney, S.L., \& Cox, E.D. (1994). Balance and proprioceptive training for rehabilitation of the lower extremity. Journal of Sport Rehabilitation, 3(1), 68-83.

17. Jukić, I., Milanović, L., Šimek, S., Nakić, J., \& Komes, Z. (2003). Metodika proprioceptivnog treninga na balans pločama. Kondicijski trening, $1(1), 55-59$.

18. Kurelić, N., Momirović, K., Stojanović, M., Šturm, J., Radojević, Đ., \& Viskić-Štalec, N. (1975). Struktura i razvoj morfoloških i motoričkih dimenzija omladine. Institut za naučna istraživanja Fakulteta za fizičko vaspitanje, Beograd.

19. Laskowski, E.R., Newcomer-Aney, K., \& Smith, J. (1997). Refining rehabilitation with proprioception training: Expediting return to play. The Physician and Sports medicine, 25(10).

20. Lephart, S.M., \& Fu, F.H. (2000). Proprioception and Neuromuscular Control and Joint Stability. Champaign, II: Human Kinetics.

21. Liu-Ambrose, T., Taunton, J.E., MacIntyre, D., McConkey, P., \& Khan, K.M. (2003). The effects of proprioceptive of strength training on the neuromuscular function of the ACL reconstructed knee: a randomized clinical trial. Scandinavian Journal of Medicine and Science in Sport, 13(2), 115-123.

22. Lukić, A. (2010). Efekti proprioceptivnog treninga na razvijanje ravnoteže i poboljšanje tehnike izvođenja u sportskom plesu. Doktorska disertacija, Univerzitet u Banja Luci, Fakultet fizičkog vaspitnja i sporta, Banja Luka. 
23. Metikoš, D., Hofman, E., Prot, F., Pintar, T,., \&Oreb, G. (1989). Mjerenje bazičnih motoričkih dimenzija sportaša (Measurement of basic motor characteristics of athletes. In Croatian). Zagreb, Faculty of Physical Culture University of Zagreb.

24. Milanović, L. (2003). 20 jardi - test za procjenu agilnosti. Kondicijski trening, 1(1), 12-13.

25. Robbins, S., \&Waked, E. (1998). Factors associated with ankle injuries. Preventive measures. Sports Medicine, 25(1), 63-72.

26. Romero-Franco, N., Martínez-López, E., Lomas-Vega, R., Hita-Contreras, F., \&Martínez-Amat, A. (2012). Effects of proprioceptive training program on core stability and center of gravity control in sprinters. The Journal of Strength \& Conditioning Research, 26(8), 2071-2077.

27. Sheppard, J. M., \& Young, W. B. (2006). Agility literature review: Classifications, trainingandtesting. Journal of sports sciences, 24(9), 919-932.

28. Sheth, P., Yu, B., Laskowski, E.R., \& An, K.N. (1997). Ankle disk training influences reaction times of selected muscle in a simulated ankle sprain. The American Journal of Sports Medicine, 25(4), 538-543.

29. Spencer, M., Dawson, B. Goodman, C., Dascombe, B., \& Bishop, D. (2008). Performance and metabolism in repeated sprint exercise: effect of recovery intensity. European Journal of Applied Physiology, 103, 545-552.
30. Šebić-Zuhrić, L., Rađo, I. i Bonacin, D. (2007). Efekti proprioceptivnog treninga na rezultate $\mathrm{u}$ specifičnim gibanjima ritmičke gimnastike. Acta Kinesiologica, 1(2007) 1:30-37.

31. Šimek, S., Milanović, D., \& Jukić, I. (2008). The effects of proprioceptive training on jumping and agility performance. Kineziologija, 39(2), 131-141.

32. Vad, V., Hong, H. M., Zazzali, M., Agi, N., \& Basrai, D. (2002). Exercise recommendations in athletes with earlyo steoarthritis of the knee. Sports medicine, 32(11), 729-739.

33. Voight, M. L., \& Cook, G. (1996). Clinical application of closed kinetic chain exercise. Journal of Sport Rehabilitation, 5(1), 25-44.

34. Wester, J.U., Jespersen, S.M., Nielsen, K.D., \& Neumann, L. (1996). Wobble board training after partial sprains of the lateral ligaments of the ankle - a prospective randomized study. Journal of Orthopaedic and Sports Physical Therapy, 23(5), 332-336.

35. Wolf-Cvitak, J., Grčić-Zubčević, N., \& Dolančić, A. (2002). Kinesthetic perception in rhythmic gymnastics open vs. closed eye performance. In D. Milanović \& F. Prot (Eds.). Kinesiology - New Perspectives, Proceedings, 3rd International Scientific Conference. Opatija, 25-29 September, pp. 253-256. Zagreb: Faculty of Kinesiology, University of Zagreb.

36. Yaggie, J. A., \& Campbell, B. M. (2006). Effects of balance training on selected skills. The Journal of Strength \& Conditioning Research, 20(2), 422-428. 


\title{
EFECTOS DE LA APLICACIÓN DE ENTRENAMIENTO PROPIOCEPTIVO SOBRE LA FUERZA, AGILIDAD Y COORDINACIÓN DE JÓVENES GIMNASTAS RÍTMICAS
}

\begin{abstract}
Resumen
El objetivo de la presente investigación era examinar la influencia del entrenamiento sobre la fuerza explosiva, agilidad y coordinación de las niñas de 7-9 años de edad que se entrenan en gimnasia rítmica. Las mediciones se realizaron en una muestra de 74 niñas sanas. La muestra se ha dividido en dos grupos: el grupo experimental (43 niñas) y el grupo de control (31 niña). El grupo experimental aplicaba el entrenamiento propioceptivo en marco de sus entrenamientos regulares RG, en período de 12 semanas (24 entrenamientos). El grupo de control asistía solo a los entrenamientos de gimnasia rítmica. Para establecer los efectos del factor experimental sobre las capacidades motrices seguidas se utilizaron los test estandarizadas para valorar la fuerza, coordinación y agilidad. Todas las niñas examinadas fueron medidas antes de la aplicación del factor experimental (preprueba) y después de su terminación (postprueba). Para establecer la diferencia en los resultados alcanzados entre la medición inicial y final para cada grupo, se utilizó prueba-t para las muestras dependientes. Para establecer la diferencia entre grupos en la medición inicial y final se utilizó prueba-t para las muestras independientes. Por análisis de los resultados de la medición inicial y final se constató progreso en todos los atributos de las capacidades motrices seguidas en el grupo experimental. En las niñas examinadas en el grupo de control se notó progreso en el espacio de coordinación y agilidad. La prueba estadística de las diferencias de los resultados entre los grupos en la medición final demostró que la diferencia entre los grupos existe solo en el espacio de agilidad a favor del grupo experimental. Sobre la base de los resultados obtenidos se llegó a conclusión que la aplicación de entrenamiento propioceptivo en las niñas incluidas en el programa de gimnasia rítmica puede contribuir al aumento de los atributos motrices que tienen influencia en la agilidad, mientras que en el espacio de las demás capacidades motrices seguidas no se puede confirmar con seguridad que se ha notado progreso como resultado de la aplicación de entrenamiento propioceptivo.
\end{abstract}

Palabras claves: PROPIOCEPCION/ CAPACIDADES MOTRICES / GIMNASIA RÍTMICA / NIÑAS

Примљен: 16. 10. 2017

Прихваћен: 20.03.2018 